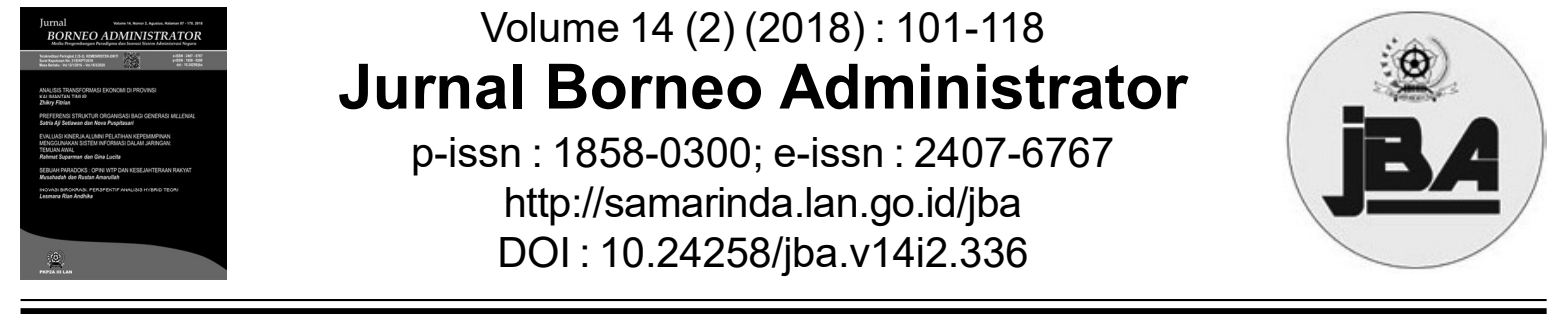

\title{
PREFERENSI STRUKTUR ORGANISASI BAGI GENERASI MILLENIAL
}

\section{THE PREFERENCE OF ORGANIZATION STRUCTURE FOR MILLENIALS}

\author{
Satria Aji Setiawan dan Nova Puspitasari \\ Kementerian Keuangan, \\ Jl. Purnawarman Nomor 99, Kebayoran Baru, Jakarta \\ Email: satria.asetiawan@gmail.com; nvpuspita@gmail.com
}

Naskah diterima: 31 Maret 2018; revisi terakhir: 18 Mei 2018; disetujui: 21 Mei 2018

\begin{abstract}
Millennial or Y generation is a generation born between 1981 and 2003. They are the generation that likes flexibility, freedom as well as personal things. Their work attitude is different from previous generations, one of which is that millenial generation has a strong preference related to the organizational structure and the systems that support it. This study was conducted to analyze millennial generation preferences related to the organizational design continuum, whether millennials are more likely to mechanistic designs or more to organic organizational design. In addition, this study aims to provide strategic recommendations for designing organizational structures that can accommodate millennial needs.

This research used mixed research methods by combining quantitative methods through descriptive statistical analysis and qualitative methods. Based on the research, it is known that millennials prefer to work in organizations that have organic structures with few characteristics of mechanistic organization. The ideal organization for millenial generation is an organization that has low complexity, low centralization, high formalization, low stratification, high adaptability, low production, high efficiency, and high job satisfaction.
\end{abstract}

Keywords: Millenials, Organization Structure, Mechanistic, Organic

\begin{abstract}
Abstrak
Generasi millenial atau generasi Y adalah generasi yang lahir diantara tahun 1981 sampai dengan 2003. Mereka adalah generasi yang cenderung lebih fleksibel dan menyukai kebebasan serta hal yang sifatnya personal. Sikap kerja mereka pun berbeda dengan
\end{abstract}


generasi-generasi sebelumnya, salah satunya adalah generasi millenialmemiliki preferensi yang kuat terkait dengan struktur organisasi dan sistem yang mendukungnya. Penelitian ini dilakukan untuk menganalisis mengenai preferensi generasi millenial terkait dengan kontinum desain organisasi, apakah generasi millenial lebih cenderung kepada desain mekanistik atau lebih condong kepada desain organisasi organik. Selain itu, penelitian ini bertujuan untuk memberikan rekomendasi strategis untuk menyusun desain struktur organisasi yang mampu mengakomodasi kebutuhan generasi millennial.

Penelitian ini menggunakan metode penelitian campuran dengan menggabungkan metode kuantitatifmelalui analisis statistika deskriptif dan metode kualitatif. Berdasarkan penelitian, diketahui bahwa generasi millenial lebihmemilih untuk bekerja di organisasi yang memiliki struktur organik dengan sedikit karakteristik organisasi mekanistik. Organisasi yang ideal bagi generasi millenial adalah organisasi yang memiliki kompleksitas rendah, sentralisasi rendah, formalisasi tinggi, stratifikasi rendah, kemampuan adaptasi tinggi, produksi rendah, efisiensi tinggi, dan kepuasan kerja tinggi.

Kata kunci: Generasi Millenial, Struktur Organisasi, Mekanistik, Organik

\section{A. PENDAHULUAN}

Penelitian tentang pengelompokan generasi didasarkan pada teori kelompok generasi yang disampaikan oleh Karl Mannheim pada tahun 1928 (Smelser, 2001). Pengelompokan generasi di dalam populasi didasarkan pada pengalaman atau peristiwa besar yang terjadi, bukan secara kelas social maupun geografi (Sessa, et al., 2007). Sebagai generasi yang matang, ia mengembangkan karakteristik yang membedakannya dari generasi sebelumnya, yaitu kepribadian, nilai kerja, sikap, dan motivasi (Smola dan Sutton, 2002).

Pengelompokan generasi dibagi menjadi enam, yaitu generasi WWII, generasi silent, generasi baby boomer, generasi X, generasi millenial atau generasi Y, dan generasi Z. Kriteria untuk kapan sebuah generasi dimulai dan berakhir berhubungan dengan peristiwa besar yang terjadi pada saat itu. Salah satu contohnya adalah generasi silent yang dimulai pada tahun 1925 karena saat itu terjadi kelahiran bayi secara besar-besaran setelah Perang Dunia I. Generasi silent berakhir pada tahun 1945 karena Perang Dunia II berakhir dan tingkat kelahiran yang menandai generasi silent berangsur turun (Troksa, 2016:8). Adapun periodisasi generasi dapat digambarkan dalam tabel berikut:

Tabel 1.

Periodisasi Generasi

\begin{tabular}{|l|l|l|}
\hline Nama Generasi & Tahun Kelahiran & Peristiwa Besar \\
\hline $\begin{array}{l}\text { Generasi WWI (Perang } \\
\text { Dunia Ke II) }\end{array}$ & $1901-1924$ & $\begin{array}{l}\text { Depresi Besar } \\
\text { Perang Dunia II }\end{array}$ \\
\hline Generasi Silent & $1925-1945$ & $\begin{array}{l}\text { Akhir Perang Dunia II dan } \\
\text { Depresi Besar }\end{array}$ \\
\hline Generasi Baby Boomer & $1946-1964$ & $\begin{array}{l}\text { Pergerakan Hippie } \\
\text { Perang Vietnam } \\
\text { Hukum Anti Segregasi }\end{array}$ \\
\hline Generasi X & $1965-1980$ & $\begin{array}{l}\text { Pendaratan di Bulan } \\
\text { Akhir Perang Vietnam } \\
\text { Embargo Minyak }\end{array}$ \\
\hline Generasi Millenial & $1981-2003$ & $\begin{array}{l}\text { Penyerangan WTC 9/11 } \\
\text { Resesi 2008 }\end{array}$ \\
\hline Generation Z & Ledakan teknologi \\
\hline
\end{tabular}

Sumber: Troksa (2016:8) 
Setiap generasi memiliki perbedaan karakteristik terkait banyak hal, diantaranya preferensi cara belajar, kepribadian, nilai kerja, sikap, maupun motivasi. Generasi millenial cenderung lebih menyukai cara belajar yang eksploratif (learning by doing), bertindak secara fleksibel, memiliki banyak preferensi pribadi, cenderung kurang sabar, berorientasi hasil, dapat mengerjakan beberapa hal secara bersamaan (multitasking), mudah beradaptasi dengan teknologi, menyukai cara berkomunikasi yang nomadik, menyukai kerja kolaborasi, mengejar keseimbangan hidup, dan cenderung kurang suka membaca. (Sweeney, 2005).

Generasi millenial merupakan generasi produktif yang saat ini berumur 15-37 tahun. Generasi millenial bahkan secara jumlah mulai menjadi mayoritas di berbagai organisasi. Di rentang usia yang masih sangat produktif tersebut mereka menjadi pegawai, manajer lini pertama, maupun menjadi manajer menengah. Banyaknya jumlah generasi milenial dan perbedaan karakter antara mereka dengan generasi yang lebih tua tentu menjadi perhatian tersendiri, salah satunya dalam menyusun struktur organisasi yang sesuai.

Menurut teori organisasi, terdapat dua kontinum desain organisasi, yaitu organisasi mekanistik (birokrasi) dan organisasi organik. Organisasi mekanistik ditandai dengan adanya spesialisasi yang tinggi, departementalisasi yang rigid, rantai komando yang jelas, rentang kendali yang sempit, sentralisasi yang tinggi, dan formalisasi yang tinggi. Sedangkan organisasi organik ditandai dengan ciri-ciri tim lintas fungsional, tim, lintas hierarki, arus informasi yang bebas, rentang kendali yang lebar, desentralisasi, dan formalisasi yang rendah (Robbins, 2012:274).

Berbeda dengan generasi yang mendahuluinya, generasi millenial memiliki preferensi yang kuat terkait dengan struktur organisasi dan sistem yang mendukungnya. Penelitian ini dilakukan untuk menganalisis mengenai preferensi generasi millenial terkait dengan kontinum desain organisasi, apakah generasi millenial lebih cenderung kepada desain mekanistik atau organik. Selain itu, penelitian ini bertujuan untuk memberikan rekomendasi strategis untuk menyusun desain struktur organisasi yang mampu mengakomodasi kebutuhan generasi millenial.

\section{B. METODE PENELITIAN}

Penelitian ini merupakan penelitian dengan menggunakan mix method atau penelitian metode campuran. Penelitian metode campuran merupakan pendekatan penelitian yang fokus pada mengumpulkan, menganalisis, dan mengombinasikan bentuk kualitatif dan bentuk kuantitatif dalam sebuah penelitian. Penggunaan kombinasi antara pendekatan kualitatif dan kuantitatif akan menghasilkan pemahaman tentang permasalahan penelitian yang lebih memadai dibandingkan jika hanya menggunakan salah satu metode saja (Cresswell \& Clark, 2011).

Pendekatan kuantitatif dilakukan dengan menggunakan survei preferensi yang mengacu pada variabel-variabel kunci dalam pembentukan struktur organisasi yang dibagikan kepada responden dalam bentuk kuesioner. Data tersebut kemudian diolah dengan metode statistika deskriptif. Statistika deskriptif adalah metode statistika yang digunakan untuk menggambarkan atau mendeskripsikan data yang telah dikumpulkan menjadi sebuah informasi(Purwanto, 2012: 28). Pendekatan kuantitatif dilakukan untuk mengidentifikasi variabel-variabel kunci dalam pembentukan struktur organisasi yang sesuai dengan generasi millenial. Sedangkan pendekatan kualitatif dilakukan dengan melakukan focused group discussion (FGD) untuk mengeksplorasi lebih lanjut alasan pemilihan preferensi variabel-variabel kunci yang ada dalam organisasi. Pendekatan kualitatif dilakukan untuk menggali lebih dalam terkait informasi yang diperlukan untuk merumuskan rekomendasi dalam penyusunan desain struktur organisasi. 
Pengumpulan data dilakukan dengan menggunakan data primer menggunakan metode survei kepada 111 orang mahasiswa Politeknik Keuangan Negara STAN yang dilakukan secara acak. Responden berada pada rentang tahun kelahiran antara tahun 1998 sampai dengan tahun 2001. Selanjutnya para responden diarahkan untuk melakukan FGD untuk mengeksplorasi alasan preferensi variabel struktur organisasi yang dipilih.

Adapun data dan informasi pendukung lainnya diperoleh dari sumber-sumber dan literatur lain, contohnya buku, jurnal, hasil penelitian, serta sumber-sumber lainnya yang menunjang penelitian ini. Keseluruhan data yang digabung kemudian dianalisis secara deskriptif kualitatif. Adapun keterbatasan penelitian ini adalah keseluruhan sampel diambil dari generasi millenial yang sedang menempuh pendidikan di Perguruan Tinggi Kedinasan.

\section{KERANGKA TEORI}

\section{Generasi Millenial}

Pengelompokan generasi menurut Brosdahl dan Carpenter (2011) dibagi menjadi enam, yaitu generasi WWII (1901-1924), generasi silent (1925-1945), generasi baby boomer (19461964), generasi X (1965-1980), generasi millenial (1981-2003), dan generasi Z (2003sekarang).

Generasi millenial atau sering disebut generasi Y merupakan generasi yang menarik perhatian, baik bagi manajer maupun akademisi. Generasi ini merupakan generasi pertama yang menghabiskan seluruh hidup mereka pada lingkungan digital, yang tentu saja berimplikasi pada bagaimana cara mereka hidup dan bekerja (Bennett et al, 2008, Wessner and Miller, 2008). Menurut beberapa penelitian, generasi ini disebut greatest generation (Howe \& Strauss, 2000:51), namun ada juga yang menyebut sebagai generasi cengeng, yaitu anak-anak muda yang memperturutkan kemauan hati secara berlebihan dan dilindungi secara berlebihan yang tidak mampu mengatasi pekerjaan yang biasa saja tanpa adanya petunjuk atau bantuan (Hershatter \& Eppstein, 2010).

Generasi millenial diantaranya ditandai dengan karakteristik sebagai berikut:

a) Digital Immersion

Generasi millenial tidak hanya nyaman dengan menggunakan teknologi, teknologi adalah bagian yang terintegrasi dari generasi millenial. Teknologi dan perkembangannya tersebut sangat berpengaruh untuk generasi ini (Tapscott, 2009).

b) Mentalitas open source

Kekuatan dari generasi millenial berasal dari pengaruh facebook, twitter, Wikipedia, dan media social lain yng memiliki pengaruh dalam membentuk perdagangan, politik, Pendidikan, dan struktur social. Bentuk baru dalam berkomunikasi dalam pengiriman pesan dengan menyingkat pesan yang disampaikan (Sujansky, 2009). Berdasarkan pengalaman mereka, generasi millenial memiliki asumsi bahwa semua informasi penting dapat dikumpulkan dengan sentuhan tangan/melalui gawai (Hershatter \& Epstein, 2010).

c) Content Creation

Generasi millenial tidak pernah puas hanya dengan mendapatkan dan menggunakan informasi; mereka juga akan mncari cara untuk membuat informasi melalui blog, media interaktif, twitter, dan media sosial lainnya (Jones \& Fox, 2009). Membagikan informasi lewat blog adalah salah satu contoh yang membuktikan bahwa generasi millenial ingin menangkap, mengorganisasikan, dan menyebarkan pemikiran, opini, dan pengalaman mereka (Hershatter \& Eppstein, 2010). Kecenderungan ini disebutkan oleh Psikolog Jean Twenge 
sebagai generation me, yaitu orang-orang yang memiliki karakteristik lebih ambisius, asertif, dan bahkan lebih narcissistic daripada generasi sebelumnya (Twenge, 2009).

d) Menyukai fleksibilitas

Generasi millenial adalah generasi yang meyukai fleksibilitas kerja dan karir. Selanjutnya, sebagai digital native, generasi millenial percaya bahwa mereka dapat bekerja dengan lebih efisien dengan memanfaatkan teknologi, contohnya adalah menghilangkan waktu untuk hal-hal yang tidak perlu, non-esensial, interaksi tatap muka yang terjadi dalam pengaturan kantor pada umumnya (Erickson, 2008:177).

Nilai-nilai generasi millenial, berdasarkan karakteristik yang disusun oleh Gibson, Greenwood, dan Murphy (2009) dihubungkan dengan atribut kerja yang dirumuskan oleh Espinoza, Ukleja, dan Rusch (2011) disimpulkan oleh Dannar (2013) sebagai berikut:

Tabel 2.

Nilai-Nilai Generasi Millenial Dalam Lingkungan Kerja

\begin{tabular}{|l|l|}
\hline Nilai-Nilai & Dalam Lingkungan Kerja \\
\hline Keamanan keluarga & $\begin{array}{l}\text { Keamanan keluarga merupakan prasyarat dasar bagi } \\
\text { seseorang di lingkungan kerja }\end{array}$ \\
\hline Kesehatan & Keseimbangan antara pekerjaan dengan kehidupan lain \\
\hline Kebebasan & Mengekspresikan diri melalui cara yang personal \\
\hline Kejujuran & $\begin{array}{l}\text { Lebih menyukai hal yang bersifat sederhana dan informal- } \\
\text { dasi dan jas dianggap sebagai sebuah bentuk keangkuhan } \\
\text { dan menutupi dari kenyataan. }\end{array}$ \\
\hline Tanggung jawab & Berorentasi pada pencapaian \\
\hline $\begin{array}{l}\text { Hubungan } \\
\text { pertemanan }\end{array}$ & $\begin{array}{l}\text { Keseimbangan pada hidup dan pekerjaan- pendekatan } \\
\text { jaringan dan pertemanan }\end{array}$ \\
\hline Kemandirian & Senang mencari perhatian, misalnya melalui media sosial \\
\hline Rasa ingin dihormati & $\begin{array}{l}\text { Mencari arti dari setiap pekerjaan, bahkan untuk pegawai } \\
\text { golongan awal }\end{array}$ \\
\hline Ambisius & Ingin diberikan penghargaan \\
\hline
\end{tabular}

Sumber: Dannar (2013)

\section{Struktur Organisasi}

Dalam mencapai tujuan bersama, maka penentuan struktur organisasi menjadi hal yang krusial. Banyak definisi dan pendapat yang berbeda mengenai struktur organisasi. Struktur adalah serangkaian kewajiban yang perlu dilakukan dalam mencapai tujuan organisasi yang tergambarkan dalam tabel organisasi (Jackson dan Morgan, 1982:81). Dalam terminologi lain disebutkan bahwa struktur adalah arsitektur dari kompetensi bisnis, kepemimpinan, talenta, dan pengaturan hubungan fungsional (Wolf, 2002). Walton (1985:238), mengidentifikasi struktur sebagai dasar dari organisasi, termasuk tingkatan hierarki, rentang kendali, jabatan dan peran, mekanisme kerja, dan cara pemecahan masalah. Berdasarkan kamus perilaku organisasi (“Dictionary-Organizational Behavioral," 2012), struktur organisasi didefinisikan sebagai pola hubungan antar komponen dan bagian dari organisasi.

Dalam menyusun struktur organisasi, terdapat enam hal yang perlu dipertimbangkan, yaitu sebagai berikut: 
a. Spesialisasi Kerja

Hakikat spesialisasi kerja adalah bahwa seluruh pekerjaan dipecah-pecah menjadi sejumlah langkah dan tiap langkah diselesaikan oleh individu yang berlainan, bukannya keseluruhan pekerjaan dilakukan oleh satu individu.

b. Departementalisasi

Setelah pekerjaan dibagi-bagi melalui spesialisasi kerja, perlu dilakukan pengelompokan pekerjaan tersebut sehingga tugas yang sama/mirip dapat dikoordinasikan. Dasar yang digunakan untuk pengelompokan ini, disebut departementalisasi. Departementalisasi pekerjaan dapat dilakukan menurut fungsinya (akuntansi, personalia, manufaktur, riset \& pengembangan), pelanggan, jenis produk, geografis/teritori, dan prosesnya.

c. Rantai Komando

Rantai komando merupakan garis wewenang yang tidak terputus-putus, yang terentang dari puncak organisasi ke eselon terbawah dan memperjelas siapa melapor kepada siapa. Ada dua konsep komplementer yang perlu dipahami tentang rantai komando tersebut, yakni:

1) Wewenang (hak-hak yang melekat dalam posisi manajerial untuk memberi perintah dan mengharapkan perintah itu dipatuhi); dan

2) Kesatuan Komando (bawahan seharusnya memiliki satu atasan kepada siapa bawahan tersebut bertanggung jawab langsung).

d. Rentang Kendali

Rentang kendali berkaitan dengan jumlah bawahan yang dapat dikendalikan oleh seorang manajer secara efisien dan efektif.

e. Sentralisasi dan Desentralisasi

Sentralisasi/desentralisasi mengacu pada tingkat pengambilan keputusan dipusatkan pada satu titik tunggal dalam organisasi. Jika manajemen mengambil keputusan utama organisasi dengan sedikit atau tanpa masukan dari personil di tingkat lebih bawah, keputusan organisasi tersebut dinamakan tersentralisasikan. Sebaliknya, jika makin banyak personil pada tingkat lebih bawah diberi keleluasaan untuk mengambil keputusan, keputusan tersebut disebut pengambilan keputusan dalam organisasi tersebut didesentralisasikan.

f. Formalisasi

Formalisasi mengacu pada tingkat pekerjaan di dalam suatu organisasi itu dibakukan. Jika pekerjaan sangat diformalkan, pelaksana pekerjaan itu mempunyai kuantitas keleluasaan yang minimum mengenai; apa yang harus dikerjakan, kapan harus dikerjakan, dan bagaimana seharusnya ia mengerjakannya.

Pada organisasi dengan formalisasi yang tinggi, terdapat uraian jabatan dalam bentuk tertulis, banyak aturan organisasi dan prosedur yang terdefinisikan dengan jelas mengenai proses kerja dalam organisasi. Sementara pada organisasi dengan formalisasi rendah, perilaku kerja relatif tidak terprogram dan para karyawan mempunyai banyak keleluasaan dalam menjalankan pekerjaannya.

\section{Kontinuum Struktur Organisasi}

Secara umum, struktur organisasi dibedakan menjadi dua, yaitu mekanistik dan organik. Mekanistik dan organik adalah dua kutub berseberangan dari kontinuum terkait kemungkinan struktur organisasi. Menurut (Tom Burns dan G. M. Stalker 1961) dalam Sine, Mitsuhasi, dan Kirsch (2008), organisasi mekanistik memiliki struktur organisasi yang lebih rigid dan biasanya ditemukan di lingkungan yang cenderung stabil dan dapat diprediksi. Karakteristik organisasi mekanistik adalah: 
a. Pekerjaan yang ada dalam organisasi dibagi habis ke dalam bagian kecil yang terspesialisasi.

b. Definisi yang jelas dan pasti terkait hak, kewajiban, tanggung jawab, dan metode teknis tiap jabatan. Adanya struktur hierarki, kewenangan dan komunikasi.

c. Pengetahuan keseluruhan organisasi tersimpan secara eksklusif pada pucuk pimpinan organisasi

d. Terdapat arus komunikasi secara vertikal, contohnya: atasan dengan bawahan.

Sedangkan organisasi organik sifatnya lebih cair dan sesuai dalam lingkungan yang berubahubah. Karakteristik dari organisasi organik adalah:

a. Tiap individu berkontribusi ke dalam organisasi dan ada penyesuaian dan pendefinisian ulang uraian jabatan tiap individu melalui interaksi dengan individu lain.

b. Arus komunikasi yang lebih luwes dan lateral, bukan vertikal.

c. Pengetahuan bisa bersumber dari mana saja di organisasi, tidak hanya menjadi konsumsi pimpinan level atas.

d. Kepentingan dan prestise melekat pada afiliasi dan keahlian yang berlaku dalam lingkungan tertentu.

\section{Desain Mekanistik}

Organisasi mekanistik adalah hasil yang alamiah dalam mengombinasikan enam elemen kunci organisasi. Desain mekanistik merupakan desain organisasi yang menekankan pada kepentingan pencapaian produksi yang tinggi dan efisien melalui penggunaan aturan dan prosedur yang ekstensif, sentralisasi wewenang, dan spesialisasi tenaga kerja yang tinggi. Mengacu pada asas kesatuan komando, desain mekanistik memiliki hierarki dan kewenangan yang formal, dengan tiap orang dikendalikan dan disupervisi oleh satu supervisor. Berdasarkan rentang kendali, rentang kendali desain mekanistik relatif kecil dan memiliki level penjenjangan yang relatif tinggi dalam organisasi. Dikarenakan adanya jarak antara pimpinan puncak dan pegawai dalam organisasi, pimpinan puncak akan memperjelas peraturan dan regulasi. Hal ini dikarenakan pimpinan puncak tidak akan mampu mengendalikan kegiatan pegawai pada tingkat bawah, mereka menggantinya dengan peraturan dan regulasi yang lebih rigid. (Robbins, 2012:274).

Max Weber (1947:330-332) membuat kontribusi penting terhadap model mekanistik. Ia menjelaskan aplikasi model mekanistik dan istilah birokrasi. Dalam pandangan Max Weber, birokrasi ditujukan pada cara tertentu dalam mengorganisasikan suatu kumpulan aktivitas. Minat Weber dalam birokrasi mencerminkan kepeduliannya dalam hal cara masyarakat mengembangkan hierarki pengendalian sehingga satu kelompok bisa mendominasi kelompok lain. Desain organisasi melibatkan dominasi wewenang dimana wewenang mengkaitkan legitimasi untuk meminta kepatuhan dari pihak lain. Pencariannya akan bentuk dominasi yang berkembang di masyarakat menuntunnya untuk mempelajari struktur birokrasi.

Menurut Weber, struktur birokrasi adalah superior dari bentuk lainnya dalam ketepatan, dalam stabilitas, dalam ketentuan disiplin dan kendalanya. Untuk mencapai manfaat maksimum dari desain birokrasi, Weber percaya bahwa organisasi harus mempunyai karakteristik sebagai berikut:

a) Semua tugas akan dibagi dalam pekerjaan-pekerjaan yang sangat spesialis. Melalui spesialisasi, pemegang kerja menjadi ahli dalam pekerjaan mereka, dan manajemen bisa meminta mereka bertanggung jawab atas efektivitas prestasi tugas-tugas mereka.

b) Masing-masing tugas dikerjakan menurut suatu sistem dengan aturan abstrak untuk menjamin kesatuan dan koordinasi dari tugas-tugas yang berbeda. Rasionalnya dari praktik ini adalah manajer dapat menghilangkan ketidakpastian kinerja tugas karena perbedaan individu. 
c) Masing-masing anggota atau kantor suatu organisasi bertanggung jawab atas kinerja pekerjaan untuk satu dan hanya satu manajer. Manajer memiliki wewenang mereka karena pengetahuan dan didelegasikan dari hierarki puncak.

d) Masing-masing karyawan organisasi berhubungan dengan karyawan lain, dan klien dalam bentuk non pribadi, sisi formal, menjaga jarak sosial dengan bawahan dan pelanggan. Tujuan dari praktik ini adalah menjamin bahwa kepribadian dan favoritisme tidak mencampuri pencapaian efisiensi dari sasaran organisasi.

e) Pekerjaan dalam organisasi yang birokratis didasarkan pada kualifikasi teknis dan dilindungi terhadap pemecatan sewenang-wenang. Hal yang sama, promosi didasarkan atas senioritas dan pencapaian. Kerja di organisasi dipandang sebagai karir jangka panjang, dan loyalitas tinggi dapat ditimbulkan.

Model Mekanistik mencapai tingkat produksi dan efisiensi yang tinggi berkaitan dengan karakteristik sebagai berikut:

a) Sangat kompleks karena menekankan pada spesialisasi tenaga kerja.

b) sangat tersentralisasi karena menekankan pada wewenang dan tanggung gugat (accountability).

c) Sangat formal karena menekankan pada fungsi sebagai dasar departemen.

\section{Desain Organik}

Organisasi organik adalah organisasi yang memiliki daya adaptasi tinggi terhadap perubahan yang berasal dari eksternal organisasi. Organisasi ini sifatnya lebih bebas dan fleksibel dibandingkan organisasi mekanistik yang sifatnya lebih rigid dan stabil. Organisasi ini tidak mengutamakan pekerjaan dan regulasi yang terstandardisasi, bahkan mengizinkan perubahan struktur organisasi secepat mungkin sesuai dengan kebutuhan. Desain organik memiliki pembagian tenaga kerja, tapi pekerjaan dari orang-orang didalamnya tidak distandardisasi. Para pegawai cenderung lebih profesional dan memiliki keahlian teknis yang memadai dan terlatih untuk menghadapi permasalahan yang beraneka ragam. Mereka memiliki beberapa peraturan yang formal dan sedikit pengawasan langsung dikarenakan mereka telah mendapatkan pelatihan yang memiliki kode etik dan standar profesi. Sebagai contoh insinyur minyak yang tidak perlu mengikuti prosedur kerja yang spesifik tentang bagaimana untuk menemukan sumber minyak lepas pantai. Para insinyur ini dapat menyelesaikan masalah mereka sendiri setelah berunding dengan rekan-rekan kerjanya. Standar profesional menuntun perilaku mereka. Organisasi yang organik memiliki sentralisasi yang rendah sehingga para profesional dapat merespon permasalahan dengan cepat sehingga pimpinan puncak mungkin tidak memiliki keahlian yang spesifik dibutuhkan untuk mengambil keputusan.

\section{Variabel-Variabel Kunci Organisasi}

Jerald Hage (1965) mengemukakan teori aksioma organisasi yang menggambarkan kerangka kerja untuk mendefinisikan dua tipe ideal organisasi, yaitu mekanistik (birokratis) dan organik (profesional). Teori tersebut mengidentifikasi delapan variabel kunci di organisasi, yaitu kompleksitas, sentralisasi, formalisasi, dan stratifikasi yang merupakan maksud organisasi untuk mencapai tujuan. Sedangkan empat variabel lainnya, yaitu tingkat adaptasi, tingkat produksi, efisiensi dan kepuasan kerja merepresentasikan kategori untuk menyortir hasil organisasi.

a. Komplekstitas

Kompleksitas atau spesialisasi merujuk pada jumlah spesialisasi di dalam organisasi termasuk panjangnya pelatihan yang diperlukan untuk masing-masing spesialisasi. Semakin banyak 
jumlah spesialis dalam sebuah organisasi dan semakin lama waktu pelatihan yang diperlukan untuk mencapai level spesialis, semakin kompleks organisasi.

b. Sentralisasi

Sering disebut juga hierarki atas wewenang merujuk pada jumlah pemangku jabatan yang terlibat dalam pengambilan keputusan dan jumlah dari ruang lingkup yang melibatkan pengambilan keputusan secara bersama-sama. Semakin rendah proporsi dari pejabat yang berpartisipasi dan semakin sedikit area pengambilan keputusan, organisasi tersebut semakin sentralistik.

c. Formalisasi

Formalisasi atau standardisasi merujuk pada proporsi dari pekerjaan yang dikodifikasi dan ragam variasi yang ditoleransi dalam parameter pendefinisian jabatan. Semakin tinggi proporsi dari pekerjaan yang dikodifikasi dalam organisasi dan semakin sedikit ragam variasi yang ditoleransi, maka semakin formal sebuah organisasi.

d. Stratifikasi

Stratifikasi atau sistem status adalah perbedaan status diantara level atas dan level bawah dalam hierarki organisasi. Perbedaan dalam pemberian gaji, prestise, dan privilege, serta fasilitas biasanya menjadi parameter dalam perbedaan status. Semakin tinggi disparitas dalam penghargaan di antara tingkat atas dan bawah dalam organisasi serta semakin rendah tingkat mobilitas antara level atas dan bawah organisasi, organisasi tersebut memiliki stratifikasi yang tinggi.

e. Kemampuan beradaptasi

Kemampuan beradaptasi atau fleksibilitas merujuk pada peggunaan pengetahuan profesional dan Teknik dalam memberikan respon terhadap perubahan lingkungan. Organisasi yang semakin adaptif ditandai dengan semakin tingginya dasar pengetahuan, teknik instruksi, dan respons terhadap lingkungan.

f. Produksi

Produksi mengacu pada kuantitas dan kualitas dari keluaran (output) organisasi. Beberapa organisasi lebih memperhatikan kuantitas daripada kualitas, dan ada pula yang sebaliknya. Variabel ini sulit untuk diukur karena dikotomi antara kuantitas dan kualitas. Semakin tinggi penekanan keluaran terkait kuantitas, maka semakin produktif sebuah organisasi.

g. Efisiensi

Efisiensi mengacu pada keuangan, sumber daya manusia, waktu, dan jumlah dari sumber daya yang tidak digunakan (idle). Semakin kecil biaya produksi per unit produksi, semakin efisien sebuah organisasi.

h. Kepuasan kerja

Kepuasan kerja atau moralitas merujuk pada jumlah kepentingan dalam organisasi untuk sumber daya manusia. Mengukur kepuasan kerja termasuk perasaan diakui, tingkat ketidakhadiran, dan tingkat perpindahan pegawai (turn over ratio). Semakin tinggi tingkat moral dan semakin rendah ketidakhadiran dan perpindahan pegawai, semakin tinggi kepuasan kerja dalam organisasi.

Inti dari pembahasan teori Hage, menurut Lunenburg (2012), terletak pada tujuh proposisi yang dikombinasikan dari teori klasik dari Max Weber (1947), Chester Barnard (1964), Charles Perrow (1972), dan Victor Thompson (1961). Delapan variabel kunci tersebut diatas saling terkait satu sama lain, yang artinya memaksimalkan satu variabel kunci organisasi berarti meminimalkan variabel kunci lainnya. Contohnya sentralisasi yang tinggi akan berpengaruh pada 
produksi dan formalisasi yang tinggi, formalisasi yang tinggi akan berdampak pada efisiensi yang tinggi, stratifikasi yang tinggi berdampak pada kepuasan kerja yang rendah, dan kompleksitas yang rendah berimplikasi pada rendahnya sentralisasi. Hal-hal tersebut dapat disampaikan secara ringkas dalam tujuh proposisi dasar sebagai berikut:

a. Semakin tinggi sentralisasi, semakin tinggi produksi

b. Semakin tinggi formalisasi, semakin tinggi efisiensi

c. Semakin tinggi sentralisasi, semakin tinggi formalisasi

d. Semakin tinggi stratifikasi, semakin tinggi produksi

e. Semakin tinggi stratifikasi, semakin rendah kepuasan kerja

f. Semakin tinggi stratifikasi, semakin rendah kemampuan beradaptasi

g. Semakin tinggi kompleksitas, semakin rendah sentralisasi

Keterkaitan antara delapan variabel kunci dan tujuh proposisi dasar diatas, menurut Lunenburg (2012), dapat digunakan untuk menggambarkan kontinum desain organisasi sebagai berikut:

Tabel 3.

Keterkaitan Variabel Kunci dan Tujuh Proposisi

\begin{tabular}{|l|c|c|}
\hline Variabel Kunci & Organisasi Mekanistik & Organisasi Organik \\
\hline Kompleksitas & Rendah & Tinggi \\
\hline Sentralisasi & Tinggi & Rendah \\
\hline Formalisasi & Tinggi & Rendah \\
\hline Stratifikasi & Tinggi & Rendah \\
\hline Kemampuan Adaptasi & Rendah & Tinggi \\
\hline Produksi & Tinggi & Rendah \\
\hline Efisiensi & Tinggi & Rendah \\
\hline Kepuasan Kerja & Rendah & Tinggi \\
\hline
\end{tabular}

Sumber: Lunenburg (2012)

\section{HASIL DAN PEMBAHASAN}

Para responden dibagikan kuesioner yang berisi tentang preferensi para responden terkait dengan struktur organisasi yang diukur melalui variabel-variabel kunci dalam struktur organisasi. Adapun hasil kuesioner tersebut dapat dituangkan dalam analisis statistika deskriptif sebagai berikut: 
Tabel 4.

Rekapitulasi Hasil Kuesioner

\begin{tabular}{|c|c|c|}
\hline Variabel Kunci & Frekuensi & Persentase \\
\hline Kompleksitas & 33 & $29,73 \%$ \\
Tinggi & 78 & $70,27 \%$ \\
Rendah & 11 & \\
\hline Sentralisasi & 100 & $90,91 \%$ \\
Tinggi & & \\
Rendah & 67 & $609 \%$ \\
\hline Formalisasi & 44 & $39,64 \%$ \\
Tinggi & & \\
Rendah & 11 & $9,91 \%$ \\
\hline Stratifikasi & 100 & $90,09 \%$ \\
Tinggi & & $67,57 \%$ \\
Rendah & 75 & $32,43 \%$ \\
\hline Kemampuan Adaptasi & 36 & $12,61 \%$ \\
Tinggi & & $87,39 \%$ \\
Rendah & 14 & $90,09 \%$ \\
\hline Produksi & 97 & $9,91 \%$ \\
Tinggi & 100 & $90,99 \%$ \\
Rendah & 11 & $9,01 \%$ \\
\hline Efisiensi & & \\
Tinggi & 101 & \\
Rendah & 10 & \\
\hline Kepuasan Kerja & & \\
Tinggi & & \\
Rendah & & \\
\hline
\end{tabular}

Sumber: Data Primer (diolah)

Dari data diatas dapat diketahui bahwa organisasi yang ideal bagi generasi millenial adalah organisasi yang berciri sebagai berikut:

1. Kompleksitas rendah

2. Sentralisasi rendah

3. Formalisasi tinggi

4. Stratifikasi rendah

5. Kemampuan adaptasi tinggi

6. Produksi rendah

7. Efisiensi tinggi

8. Kepuasan kerja tinggi

Apabila hasil diatas disandingkan dengan variabel-variabel kunci struktur organisasi yang membedakan antara organisasi mekanistik dan organisasi organik, maka dapat dilihat sebagaimana dalam tabel berikut: 
Tabel 5.

Preferensi Variabel Kunci

\begin{tabular}{|c|c|c|}
\hline Variabel Kunci & Organisasi Mekanistik & Organisasi Organik \\
\hline Kompleksitas & $\sqrt{ }$ & \\
\hline Sentralisasi & $\sqrt{ }$ \\
\hline Formalisasi & $\sqrt{ }$ & $\sqrt{ }$ \\
\hline Stratifikasi & & $\sqrt{ }$ \\
\hline Kemampuan Adaptasi & & $\sqrt{ }$ \\
\hline Produksi & & $\sqrt{ }$ \\
\hline Efisiensi & $\sqrt{ }$ & $\sqrt{ }$ \\
\hline Kepuasan Kerja & & \\
\hline
\end{tabular}

Sumber: Data Primer (diolah)

Dari data tersebut, dapat diketahui bahwa generasi millenial memiliki kecenderungan untuk lebih memilih organisasi dengan tipe organik. Hal ini terlihat dari pemilihan lima indikator yang mencirikan organisasi organik, yaitu sentralisasi yang rendah, stratifikasi yang rendah, kemampuan adaptasi yang tinggi, produksi yang rendah, dan kepuasan kerja yang tinggi. Meskipun demikian, dari delapan variabel-variabel kunci tersebut, generasi millenial juga memilih tiga ciri dari organisasi mekanistik, yaitu kompleksitas rendah, formalisasi tinggi, dan efisiensi tinggi.

1. Kompleksitas

Pada dasarnya generasi millenial cenderung menyukai bekerja di organisasi yang memiliki kompleksitas rendah. Sebanyak 70,27\% dari responden memilih organisasi yang memiliki kompleksitas rendah, sedangkan yang memilih organisasi dengan kompleksitas tinggi hanya sebesar 29,73\%. Pada dasarnya, generasi millenial merupakan generasi yang menyukai kebebasan dan fleksibilitas, sehingga mereka akan memiliki kecenderungan untuk tidak bekerja menetap pada satu bidang tertentu. Bahkan, jika diberikan pilihan untuk menjadi generalis atau spesialis, generasi millenial akan memilih menjadi generalis. Selain itu, generasi millenial cenderung untuk ingin tahu dan belajar hal baru, sehingga mereka ingin berpindah dari satu bidang pekerjaan ke bidang lainnya. Dalam hal ini, organisasi perlu mempertimbangkan pemberlakuan mekanisme mutasi/job rotation secara berkala untuk mempertahankan para generasi millenial di organisasinya. Responden menyampaikan dalam kutipan wawancara sebagai berikut:

"Lebih menyenangkan jika diberikan kesempatan untuk dimutasi secara berkala, sehingga bisa belajar banyak hal baru di tempat kerja atau bidang yang baru. Lagi pula, kalau terlalu lama ada di satu pekerjaan yang sama akan timbul kebosanan".

Hal senada juga disampaikan responden sebagai berikut:

"Daripada menetap lama, lebih baik dipindah atau dirotasi beberapa bulan sekali, biar ga bosen gitu. Karena pekerjaan yang sama berulang-ulang bakal bikin bosen. Kalau bisa kami coba dulu semua bidang yang ada, nah, menetapnya nanti di bidang yang paling cocok untuk kami”.

2. Sentralisasi

Generasi millenial yang memilih organisasi dengan sentralisasi yang rendah adalah sebesar $90,09 \%$. Sedangkan yang memilih organisasi dengan sentralisasi yang tinggi adalah 9,09\%. Responden menyatakan dalam kutipan wawancara sebagai berikut: 
"Kami tidak ingin segala sesuatunya diperintah dari atas, tapi kami ingin menentukan arah organisasi juga. Kami ingin berpengaruh dalam kemajuan organisasi, dilibatkan dalam pengambilan keputusan. Bahkan meskipun kadang masukan kami tidak digunakan, yang penting kami bisa menyampaikan pendapat kami. Hal ini perlu karena kami ingin dianggap ada dan bermanfaat di organisasi. Lagipula kami (millenial) lebih paham dan peka terhadap perubahan eksternal yang dapat bermanfaat bagi organisasi untuk beradaptasi”.

Perbedaan yang sangat signifikan ini menunjukkan bahwa pada dasarnya generasi millenial ingin terlibat dalam pengambilan keputusan di organisasi. Generasi millenial adalah generasi yang ingin dihormati dan mengejar eksistensi diri, termasuk dalam keterlibatan pengambilan keputusan. Mereka ingin memiliki keterlibatan terhadap kemajuan organisasi. Mereka tidak ingin hanya diperintah dan mengerjakan pekerjaan rutin. Selain itu, generasi millenial juga ingin memiliki arus komunikasi yang lebih bebas dengan para pimpinan yang ada di organisasi. Arus komunikasi sebisa mungkin diciptakan secara lateral dan tidak bersekat. Generasi millenial ingin menyumbangkan saran dan masukan untuk pengambilan keputusan organisasi. Organisasi perlu menyediakan, media atau saluran khusus agar para millenial dapat menyumbangkan pemikiran mereka, baik melalui media digital, misalnya melalui jaringan intranet organisasi, maupun media yang konvensional, misalnya kotak saran. Selain itu, organisasi perlu untuk mempertimbangkan desentralisasi terkait pengambilan keputusan, sehingga keterlibatan pegawai bisa lebih dioptimalkan.

3. Formalisasi

Lebih dari separuh responden memilih untuk bekerja di organisasi yang memiliki formalisasi tinggi, yaitu sebesar 60,36\%. Hanya 39,64\% responden yang memilih bekerja di organisasi dengan formalisasi rendah. Responden menyampaikan dalam kutipan wawancara bahwa:

"Harus ada uraian jabatan untuk memberikan kejelasan apa yang harus dilakukan, tanggungjawabnya apa, dan kewenangan yang dimiliki. Karena tanpa uraian jabatan, nanti bingung mau ngerjain apa. Kewenangannyajuga diperjelas, biar tidak bentrok satu sama lain. Kalau SOP itu perlu juga, tapi jangan terlalu detail. Kalau terlalu detail, ruang geraknya terlalu dibatasi, kurang bisa mengimprovisasi diri. Lebih kerasa dimanusiakan kalau diberikan ruang untuk berekspresi, caranya ya itu jangan terlalu dibatasi dengan detail cara ngerjain sesuatu”.

Meskipun generasi millenial menyukai kebebasan dan fleksibilitas, namun mereka ingin kebebasan yang terbatas pada beberapa hal. Generasi millenial memilih bekerja di organisasi yang memiliki kejelasan tentang apa kewajiban mereka, hal apa yang menjadi kewenangan mereka, serta apa tanggung jawab mereka. Namun dalam hal ini mereka tidak menyukai diberikan arahan yang terlalu detail, baik secara informal maupun secara formal. Pemberian Standard Operating Procedure (SOP) yang terlalu rinci dan arahan pimpinan yang terlalu detail sedapat mungkin dihindari. Organisasi perlu menyusun uraian jabatan yang sekurangkurangnya memuat hal yang harus dilakukan, kewenangan, hasil kerja, dan tanggung jawab untuk memberikan kejelasan peran bagi generasi millenial dalam melakukan pekerjaan. Namun organisasi perlu menyusun SOP yang lebih umum dan tidak rigid sehingga menyisakan ruang bagi generasi millenial untuk dapat mengekspresikan personalisasi mereka. 
4. Stratifikasi

Generasi millenial yang memilih bekerja di organisasi dengan stratifikasi yang rendah adalah sebesar $90,09 \%$. Sedangkan, hanya sebesar $9,91 \%$ responden yang memilih organisasi dengan stratifikasi tinggi. Responden menyampaikan dalam kutipan wawancara sebagai berikut:

"Kalau bisa sih naik pangkat secepatnya, bukan berdasar lama kerja. Tiap bisa menyelesaikan tugas atau proyek dengan benar, bisa dipromosikan. Jangan ada batasan minimal sudah bekerja berapa lama, karena itu kurang memotivasi. Kalau ada minimal waktunya kita bakal mikir ya ngapain kerja bagus banget kalua kurang diapresiasi, mending nunggu kalau udah waktunya”.

Pernyataan diatas senada dengan hasil penelitian Dannar(2013) yang menyatakan bahwa generasi millenial adalah generasi yang ambisius. Generasi millenial adalah generasi yang ingin dihargai (bahkan terkadang hanya untuk pamer). Mereka ingin mengejar prestasi dan berpindah ke jabatan yang lebih tinggi secepat mungkin, tanpa dibatasi oleh syarat-syarat administratif yang terkait dengan lama bekerja di suatu organisasi. Generasi millenial lebih menyukai promosi yang mengutamakan kinerja, bukan masa kerja. Organisasi perlu untuk mempertimbangkan mekanisme pemberian promosi tanpa memperhatikan masa kerja. Hal ini akan menjadi hal yang menarik dan memacu generasi millenial untuk bekerja dengan lebih optimal.

\section{Kemampuan Beradaptasi}

Sebanyak $67,57 \%$ generasi millenial memilih bekerja di organisasi yang lebih adaptif terhadap perubahan. Hanya $32,43 \%$ responden yang memilih bekerja di organisasi yang memiliki kemampuan adaptasi rendah.

"Kami generasi yang peka terhadap perubahan. Bahkan, perubahan itu dari generasi kami, jadi organisasi perlu untuk menyesuaikan dengan perubahan yang ada. Lagipula yang paling penting bagi organisasi untuk tetap exist adalah kemampuan adaptasinya".

Kemampuan beradaptasi terkait erat dengan salah satu karakteristik generasi millenial, yaitu fleksibel. Dengan fleksibilitas yang mereka miliki, generasi millenial menginginkan organisasi tempat mereka bekerja dapat sama fleksibelnya dengan mereka. Perubahan yang ada, baik yang berasal dari dalam maupun luar organisasi, perlu disikapi dengan baik dan organisasi perlu beradaptasi. Terlebih lagi, di era disruptif sekarang ini, daya adaptasi mutlak menjadi hal yang sangat penting untuk dimiliki organisasi. Organisasi perlu untuk lebih peka dalam merespons perubahan yang ada dan melibatkan para generasi millenial dalam pengambilan keputusan.

6. Produksi

Generasi millenial yang memilih organisasi dengan produksi yang tinggi hanya sebesar 12,61\%. Sebanyak $87,39 \%$ responden memilih untuk bekerja di organisasi yang memiliki produksi rendah.

"Pekerjaan yang lebih penting kualitas, bukan kuantitas. Kalau fokus ke kuantitas jadi seperti mesin di pabrik. Hasil kerja harus berkualitas, karena disitu ada kepuasan dalam bekerja. Pekerjaan harus melibatkan pikiran, jangan Cuma sekedar kerja. Pekerjaan yang berkualitas dapat lebih dibanggakan daripada cuma banyak yang dikerjakan".

Organisasi yang memiliki produksi tinggi diartikan oleh millenial sebagai organisasi yang lebih sedikit melibatkan proses berpikir, sehingga mereka cenderung menghindari organisasi yang seperti ini. Mereka tidak ingin mengedepankan kuantitas pekerjaan dan mengesampingkan 
kualitas pekerjaan. Bahkan, jika harus memilih, millenial cenderung untuk memberikan hasil kerja yang berkualitas dalam kuantitas kecil daripada harus memberikan hasil kerja yang memiliki kuantitas tinggi tapi mengesampingkan kualitas. Generasi millenial ingin bekerja dan mengaktualisasikan dirinya, bukan hanya sekedar bekerja dengan cepat seperti mesin.

7. Efisiensi

Generasi millenial menginginkan bekerja di organisasi yang memiliki efisiensi tinggi, bahkan $90,09 \%$ responden yang memilihnya. Hanya $9,91 \%$ responden yang menyukai bekerja di organisasi yang memiliki efisiensi rendah.

"(Di era) Sekarang yang penting kerjaan selesai, mau dikerjakan dimanapun sebenarnya bukan masalah. Pekerjaan sebenarnya bisa diselesaikan sambil di rumah atau di tempat lain, tidak harus di tempat kerja. Rapat juga seperlunya saja, ga perlu lama-lama, bahkan ga perlu ketemu. Sekarang sudah banyak teknologi yang mendukung untuk virtual meeting. Koordinasi selanjutnya juga kan bisa menggunakan whatsapp group atau slack".

Sebagai generasi yang sangat paham dengan teknologi (digital native), generasi millenial cenderung memanfaatkan teknologiuntuk memangkas waktu dan menghemat jarak. Komunikasi kerja tanpa melalui tatap muka, bahkan bekerja tanpa perlu ke tempat kerja (remote working) menjadi idaman para generasi millenial. Oleh karena itu, organisasi perlu mempertimbangkan mekanisme remote working dan berkomunikasi menggunakan teknologi daripada mengandalkan tatap muka.

8. Kepuasan kerja

Kepuasan kerja menjadi salah satu prioritas pertama bagi para generasi millenial. Responden yang memilih bekerja di organisasi yang memberikan kepuasan kerja tinggi mencapai $90,99 \%$. Hanya $9,01 \%$ yang ingin bekerja di organisasi yang memberikan kepuasan kerja rendah.

"Penting banget untuk dianggap di tempat kerja dan diperlakukan dengan baik di tempat kerja. Selain itu mengerjakan pekerjaan yang sesuai passion juga penting. Sangat tersiksa kalau tiap hari harus mengerjakan sesuatu yang ga kita sukai. Uang itu penting, tapi hidup ga melulu soal uang. Gaji yang penting mencukupi, tapi kerja sesuai passion dan dianggap penting di tempat kerja. Itu lebih penting daripada gaji gede tapi di kantor ga dianggep”.

Isu generasi millenial bukan lagi tentang imbalan finansial, tetapi lebih kepada hal-hal yang sifatnya nonfinansial. Kepuasan dalam bekerja, yaitu merasa dianggap di tempat kerja, diperlakukan dengan baik, dan mengerjakan pekerjaan yang disukai jauh lebih diutamakan daripada hanya sekedar imbalan finansial. Bahkan, generasi millenial tidak akan segan untuk berpindah tempat kerja apabila tidak mendapatkan kepuasan kerja, meskipun diberikan imbalan finansial yang cukup.

\section{E. PENUTUP}

Generasi millenial pada dasarnya lebih cenderung memilih untuk bekerja di organisasi dengan desain struktur yang dominan dengan struktur organik, meskipun masih terdapat beberapa variabel yang ada pada organisasi dengan corak mekanistik. Generasi millenial adalah generasi yang fleksibel dan menyukai kebebasan, tapi bukan kebebasan yang tanpa batas. Mereka menyukai kejelasan peran, tanggung jawab, dan kewenangan, tapi tidak menyukai pemberian arahan yang terlampau 
rigid (Hershatter \& Epstein, 2010; Erickson, 2008; Dannar, 2013). Berdasarkan penelitian ini, terdapat beberapa hal yang perlu dipertimbangkan dalam menyusun struktur organisasi dengan karakteristik sebagai berikut:

1. Menyusun dan mengimplementasikan mekanisme mutasi jabatan bagi para pegawai. Perlu disusun pola mutasi yang jelas bagi para pegawai untuk mencegah kebosanan sehingga pegawai dapat memberikan performa terbaiknya.

2. Mendesentralisasikan pengambilan keputusan organisasi dan melibatkan pegawai dalam pengambilan keputusan. Pada dasarnya generasi millenial ingin lebih dilibatkan dalam kemajuan organisasi. Mereka ingin lebih didengar dan diperhatikan pendapatnya. Organisasi dapat membentuk saluran komunikasi untuk menampung saran-saran dari para pegawai.

3. Mempertimbangkan media komunikasi nonklasikal dalam pekerjaan. Kemajuan teknologi berimplikasi pada semakin mudahnya komunikasi antar manusia. Organisasi perlu mempertimbangkan penggunaan media nonklasikal dalam pekerjaan, misalnya dengan menggunakan video conference daripada rapat konvensional.

4. Mempertimbangkan pola kerja jarak jauh (remote working). Dalam hal pekerjaan tidak mempersyaratkan kehadiran pegawai, metode pola kerja jarak jauh dapat digunakan. Hal ini dapat bermanfaat selain pada kenyamanan pegawai juga efisiensi penggunaan sumber daya kantor.

5. Memberikan kejelasan tugas para pegawai. Hal ini dapat dilakukan dengan menyusun uraian jabatan yang jelas yang sekurang-kurangnya memuat peran, hasil kerja, tanggung jawab, dan kewenangan setiap jabatan. Selain itu dapat dilakukan dengan menyusun SOP yang tidak rigid dan masih menyisakan ruang untuk berimprovisasi.

6. Menciptakan mekanisme penghargaan yang tepat. Organisasi perlu menyusun mekanisme promosi yang lebih berkeadilan berdasarkan dengan kinerja, bukan masa kerja. Selain itu organisasi perlu mempertimbangkan pemberian berbagai macam imbalan yang sifatnya non finansial, misalnya pelatihan, penghargaan pegawai terbaik, dan sertifikasi profesi bagi pegawai berprestasi.

\section{DAFTAR PUSTAKA}

Bennett, S., Maton, K. and Kervin, L. (2008). The 'Digital Natives' Debate: a Critical Review of The Evidence, British Journal of Educational Technology, 39 (5), 775-786.

Brosdahl, D.J. and Carpenter, J.M. (2011). Shopping Orientations of Us Males: A Generational Cohort Comparison, Journal of Retailing and Consumer Services, Vol. 18, 548-554.

Creswell, J. W., and Plano Clark, V. L. (2011). Designing and conducting mixed methods research (2nd edition). Thousand Oaks, CA: Sage Publications, Inc.

Dannar, P.R. (2013). Millenials: What They Offer Our Organizations and How Leaders Can Make Sure They Deliver. The Journal of Values-Based Leadership, Vol. 6, 1-12.

Erickson, T.J. (2008). Plugged In The Generation Y Guide to Thriving at Work. Harvard Business Press: Boston.

Espinoza, C. Ukleja, M., and Rusch, C. (2011). Managing the Millenials: Discover the Competencies for Managing Today's Workforce. New Jersey: John Wiley\&Sons Inc.

Gibson, J., Greenwood, R., and Murphy, E. (2009). Generational Differences in the Workplace: Personal Values, Behaviors, and Popular Beliefs. Journal of Diversity Management, 7. 
Hage, J. (1965). An Axiomatic Theory of Organizations. Administrative Science Quarterly, Vol $10,289-320$

Hershatter, A. and Epstein, M. (2010). Millenials and the World of Work: An Organization and Management Perspective. Journal of Business Psychology, Vol. 25, 211-233.

Howe, N. and Strauss, W. (2000). Millenials Rising. New York: Vintage Books.

Jackson, J. H. and Morgan, C. P. (1982). Organization Theory (2 ${ }^{\text {nd }}$ Edition). New Jersey: Prentice Hall.

Jones, S., and Fox, S. (2009). Generations online in 2009. Retrieved from http://www.pew internet.org/Reports/2009/Generations-Online-in-2009 diakses pada tanggal 23 Maret 2018.

Lunenburg, F.C. (2012). Mechanistic-Organik Organizations-An Axiomatic Theory: Authority Based on Bureaucracy or Profesional Norms. International Journal of Scholarly Academic Intellectual Diversity, 14 (1), 1-7.

Organizational Behavioral Dictionary. (2012). Retrieved from http://www.ivey.uwo.ca/ intlstudentsdictionary/OBdic.html diakses pada tanggal 23 Maret 2018.

Purwanto S.K., S. (2012). Statistika untuk Ekonomi dan Keuangan Modern. Jakarta: Salemba Empat.

Robbins, S.P.\& Coulter, M. (2012). Management (11 ${ }^{\text {th }}$ Edition). New Jersey: Prentice Hall.

Sessa, V.I., Kabacoff, R.I., Deal, J. and Brown, H. (2007). Generation Differences In Leader Values and Leadership Behaviors. The Psychologist-Manager Journal, 10 (1), 47.

Sine, W., Mitsuhasi H., Kirsch D. (2008). Revisiting Burns and Stalker: Formal Structure and New Venture Performance in Emerging Economic Sectors. Academic of Management Journal, 49 (1), 123.

Smelser, N.J. (2001). Mannheim, Karl (1893-1947). New York: Elsevier.

Smola, K.W. and Sutton, C.D. (2002). Generational Differences: Revisiting Generational Work Values for The New Millennium. Journal of Organizational Behavior, Vol. 23.

Sujansky, J. (2009). Spoiled, Impatient \& Entitled: Why You Need Strong Millenials In Your Workplace. Supervision.

Sweeney, R.T. (2005) Reinventing Library Buildings and Services for the Millenial Generation. Library Administration \& Management.

Tapscott, D. (2009). Grown Up Digital: How the Net Generation is Changing Your World. New York: McGraw-Hill.

Troksa, L. (2016). The Study of Generations: A Timeless Notion Within a Contemporary Context. Colorado. Department of History at the University of Colorado Boulder.

Twenge, J. (2009). Generational Changes and Their Impact In The Classroom: Teaching Generation Me. Medical Education, 47.

Walton, R.E. (1985). From Control to Commitment: Transforming Work Force Management in the US In: K. Clark, R. Hayes and C. Lorenz, Eds., The Uneasy Alliance: Managing the Productivity-Technology Dilemma. Boston: Harvard Business School Press. 
Weber, M. (1947). From Max Weber: Essays in Sociology. New York: Oxford University Press.

Wolf, D. (2002). Execution and Structure. Retrieved from http://www.dewarsloan.com/ workin\%20papersexecution\%20and20\%structure.html diakses pada tanggal 23 Maret 2018. 